\title{
Whakatauki
}

\author{
Haare Williams \\ KAUMĀTUA, WAKA ORANGA \\ Pae Arahi, New Zealand Association of Psychotherapists, Auckland
}

Ka rongo Te Po

Ka rongo Te Ao

Te waiata te tui ...

\section{The Colour Blue}

I miss the blue of Ohiwa.

People don't laugh like that any more.

Echoes of children playing

The thick thack of rain on raupo

Insects around fire at dusk.

People don't laugh like that.

We kids with skins baked black

Jumped off the wharf

Laughter and screams ...

One day I found Windy asleep

Yet her body told me

She was expecting something

A drink maybe ...

Rimaha once told me

A dream is a story you don't get to read ...

Maybe Windy was just thinking

Of jumping off the pier

- with me.

(Coromandel, 2012)

Williams, H. (2012). Whakatauki. Ata: Journal of Psychotherapy Aotearoa New Zealand, 16(1), 7. DOI: 10.9791/ ajpanz.2012.01. Copyright @ 2012 New Zealand Journal of Psychotherapists Inc. 